\title{
PUBLIC ADMINISTRATION IN THE FIELD OF PROVISION OF ADMINISTRATIVE SERVICES
}

Lavrenova O. I.

\section{INTRODUCTION}

One of the key principles of public administration in Ukraine is the implementation of the concept of the service state in the activities of public administration, which envisages changing the vector of relations between public authorities and individuals. The service approach in public administration, first of all, provides the introduction of such methods and technologies, the purpose of which is to improve the quality of administrative services. The main purpose of the state is to serve the person, and the defining direction of public administration - to provide individuals with effective administrative services, the priority factor of which should be accessibility and quality.

Improving the provision of administrative services today is one of the key areas of reform processes in Ukraine, and the formation of effective mechanisms for providing quality administrative services is one of the priorities of public administration, as their implementation is aimed primarily at ensuring rights, freedoms and legitimate interests of the citizens, meeting the needs of the population, which, in turn, forms an assessment of the effectiveness of public authorities in the country. The need to improve the current legislation in the field of administrative services, revision of procedural standards for their provision in the context of implementation of European and international legal standards, as well as the introduction of information and telecommunications technologies in the field of administrative services determines the relevance of this issue.

\section{The essence of the category «administrative services»}

Today, the most common in legal doctrine is the approach to the definition of «administrative services», which is reflected in current legislation. According to this approach, administrative services are defined as the result of the exercise of power by an authorized entity, which in accordance with the law provides legal registration of conditions for the exercise by individuals and legal entities of rights, freedoms and legitimate interests at their request. This approach to the definition of this concept was first reflected in the Concept of development of the system of administrative 
services by the executive authorities, which was approved by the Order of the Cabinet of Ministers of Ukraine dated February 15, 2006. The final legislative fixing of the concept of «administrative services» took place with the adoption of the Law of Ukraine «On Administrative Services» of September 6, 2012. In accordance with Art. 1 of the mentioned Law, an administrative service is the result of the exercise of authoritative powers by a subject of administrative services provision at the request of a natural or legal person, aimed at acquiring, changing or terminating the rights and / or obligations of such a person in accordance with the law ${ }^{1}$.

The Law of Ukraine «On Administrative Services» is the main legal act in the field of administrative services provision. It not only defines the concept of administrative service, but also regulates the procedure for their provision, defines the subjects of the procedure for providing administrative services, and so on. Despite the undoubted achievements in terms of legislative regulation of the provision of administrative services, the issue of payment for administrative services still remains unresolved. Thus, to date, Ukraine has not adopted a law that would regulate the issue of payment for the provision of administrative services, in particular: the criteria for payment and gratuitous administrative services, the procedure for estimation the amount of payment, the procedure for paying administrative fees, the procedure for reimbursement of administrative fees in case of refusal to provide administrative services, etc.

Speaking of the characteristics of administrative services, we should focus on the following:

1. Administrative services are based on the public interest, which means the interest of the social community determined by the state and secured by law, the satisfaction of which serves as a condition and guarantee of its existence and development. The public interest is the main feature of the administrative service, which consists in meeting the needs of an individual in accordance with the legally established competence and provided by the subjects of public administration.

2. Administrative services are provided only on the direct initiative (application) of private persons, regardless of the form of the person's application (oral or written) and the procedure for its receipt by the authority.

3. The provision of administrative services is possible only if there is a special legal regulation of the procedure for providing such services. A person's request to the authority to take any action in his / her favour

${ }^{1}$ Про адміністративні послуги: Закон України від 06.09.2012 р. Дата оновлення: 19.04.2020 p. URL: https://zakon.rada.gov.ua/laws/show/5203-17. 
may be considered as an administrative service only when the procedure for consideration of this application is clearly regulated. An authority may not be required to provide an administrative service unless it is provided by law.

4. Administrative services are provided by a specific subject of public administration. As a general rule, for a specific administrative service a person can apply to only a certain (only one) body of power defined by law, unlike other types of appeals that can be considered and resolved by a wider range of subjects.

5. The provision of administrative services is carried out according to a clearly established procedure, and in order to receive administrative services, individuals must comply with certain requirements specified by law.

6. The result of the provision of administrative services is an administrative act of a standard form (decision, permit, license, certificate, act, registration, etc.).

7. The funding is provided from public funds, i.e. at the level of the state or territorial community ${ }^{2}$.

In recent years, the issue of improving the system of administrative services has intensified with renewed vigour. Thus, the areas of improving the activities of local self-government bodies in the provision of administrative services are contained in the Concept of local self-government and territorial government reform adopted in April 2014 ${ }^{3}$. In particular, one of the tasks of the reform is to ensure the availability and quality of administrative services in accordance with state standards, taking into account the need to ensure: territorial accessibility, which provides for the provision of services in the community where the person lives; adequate material and technical base for the provision of basic forms of administrative services (local governments must have appropriate premises and infrastructure); openness of information about services, the procedure and conditions of their provision; professionalism of administrative services.

A necessary condition for improving the efficiency of public administration in the field of administrative services is to assess the quality of administrative services, which means checking the activities of the subject of public administration for the provision of administrative services, including the result of such activities, compliance with officially established requirements and / or consumers' expectations. The most common sources of information for

\footnotetext{
2 Легеза Є.О. Щодо визначення публічних послуг в Україні. Юридичний науковий електронний журнал. 2015. № 6. С. 130.

3 Про схвалення Концепції реформування місцевого самоврядування та територіальної організації влади в Україні: Розпорядження Кабінету Міністрів України від 01.04.2014 p. Дата оновлення: 01.04.2014 p. URL: https://zakon.rada.gov.ua/laws/show/333-2014-\%D1\%80.
} 
assessing the quality of administrative services are: opinion polls (including online surveys), monitoring, peer review, internal and external audit and others ${ }^{4}$.

The basis for assessing the quality of administrative services is the relevant criterion. As a general rule, such a criterion should be suitable for developing standards for the provision of administrative services. In accordance with the order of the Cabinet of Ministers of Ukraine of February 15, 2006, which approved the Concept of development of the system of administrative services by executive authorities ${ }^{5}$, the following assess criteria will contribute the quality of administrative services: efficiency, timeliness, accessibility, convenience, openness, respect for persons, observance of the principle of equality of all citizens, professionalism. It is on the basis of these criteria the standards for the provision of administrative services should be established.

Legislative requirements for the quality of administrative services are enshrined in Art. 4 (indirectly) and Art. 7 of the Law of Ukraine «On Administrative Services». In particular, in Art. 4 of this Law defines the following basic principles of providing administrative services that can be useful in assessing the quality of services: openness and transparency; efficiency and timeliness; availability of information on the provision of administrative services; rational minimization of the number of documents and procedural actions that are necessary to obtain administrative services; accessibility and convenience for the subjects of applications. In Art. 7 of the Law of Ukraine «On Administrative Services» it is stipulated that the subject of administrative services may issue organizational and administrative acts on the establishment of its own requirements for the quality of administrative services (determination of the number of reception hours, maximum waiting time and other parameters for assessing the quality of the administrative services provision).

Among the criteria for the quality of administrative services we will define the main:

1. Availability. Availability as a criterion for the quality of administrative services can be considered from two sides. Firstly, as the most simplified rules and procedures for providing services, so that maximum communication between public administration bodies (approval, examination, notification)

\footnotetext{
${ }^{4}$ Лавренова О.І. Оцінювання якості надання адміністративних послуг: навчальний посібник/ О.І. Лавренова, Т.І.Білоус-Осінь, С.К. Могил. Одеса, 2019.56c. URL:https://hdl.handle.net/ $11300 / 12475$. DOI 10.32837/11300.12475.

5 Про схвалення Концепції розвитку системи надання адміністративних послуг органами виконавчої влади: Розпорядження Кабінету Міністрів України від 15.02.2006 р. Дата оновлення: 15.02.2006 p. URL: https://zakon.rada.gov.ua/laws/show/90-2006-\%D1\%80.
} 
is carried out within these bodies, without the involvement of a person. Secondly, the criterion of accessibility is interpreted as the actual possibility of a person to apply for the necessary administrative service. This criterion includes several indicators that significantly affect quality assessment. This is, first of all, an opportunity for consumers of services to receive information about which body they need to apply for a specific administrative service and how to find this body.

To ensure the access to information about the subjects of public administration, it is necessary to create information and reference resources (printed directories, telephone directories and services, Internet portals, etc.), where interested persons can obtain the necessary information. In addition, in the event of a direct application by the consumer to an inappropriate administrative body, its employees are obliged to provide the necessary information with which the consumer can apply to the competent body. The assessment of the quality of administrative services by the criterion of accessibility is also significantly influenced by the indicator of the territorial location of the administrative body, which takes into account certain factors: location of the body, its distance from consumers, availability of transport links, signs, access roads and parking spaces for vehicles, etc.

2. Effectiveness. The criterion of effectiveness obliges the subjects of public administration to direct their activities to meet the needs of the consumer of the service. At the same time, public administration actors should focus on achieving results, and not just formally follow the rules. Thus, the criterion of effectiveness provides an answer to the question of whether the consumer of administrative services received the result he expected (of course, if these expectations are legitimate).

3. Timeliness (urgency, efficiency). The content of the criterion of timeliness is the time limit for the provision of administrative services. The service must be provided no later than a specified period, taking into account the specific needs of the person in a particular situation. In certain categories of cases, the possibility of accelerated service provision should be provided (in exceptional cases, for an additional fee, etc.). The main indicators of the optimal term should be the substantiated consumer expectations and the real ability of the body to meet certain deadlines.

4. Convenience. Convenience as a criterion for assessing the quality of administrative services determines the extent to which the interests and needs of service consumers in the organization of administrative services in a particular body are taken into account. Convenience, in particular, includes: 
- providing consumers with the opportunity to choose the method of applying for an administrative service and information on its provision (for example, in person, by mail, e-mail, etc.);

- receiving administrative services and paying for them in one place;

- no more than two appeals to the subjects of public administration (when applying for the service and when receiving a positive result);

- the opportunity for a person to visit an administrative body without excessive (disproportionate) expenditure of time, money and other efforts;

- establishment by the administrative body of a convenient schedule of reception of private persons taking into account their interests.

5. Openness. The criterion of openness presupposes the openness and availability of information necessary for consumers of administrative services (for example, what documents must be submitted to receive the service, how long the person's application will take, the amount and procedure of payment, who is responsible for providing the service, etc.), which employees of public administration bodies must provide in the form of filling out applications, forms, explaining the order and procedure for obtaining administrative services, assistance in the selection and execution of documents, etc.

6. Minimum (fair) cost of administrative service and availability of its payment. This criterion implies that the cost of administrative services, as a general rule, should not exceed the cost of actual costs of providing this type of service, i.e. to correspond to its prime cost. The standard should also be a centralized definition of a single for all regions of the state fee for administrative services in a fixed amount in the form of a single payment, which should be known in advance to consumers and, as a rule, set and implemented in a certain amount. In addition, public administration bodies should create conditions to ensure the convenience of the procedure for payment for administrative services. Payment for the provision of administrative services must be made directly on the premises of the administrative body.

7. Professionalism. The criterion of professionalism presupposes the level of qualification of employees of public administration bodies, revealed during the provision of administrative services, knowledge and observance of the procedure for the provision of administrative services, availability of skills of work with consumers, etc. The professionalism of the employee is manifested in the validity of the requirements relating to the consumer, the specificity and correctness of the comments to the submitted documents and so on. 
8. Respect for the person. The criterion of the respect for the person presupposes a polite (respectful) attitude to the person, his honour and dignity. This criterion also includes: the willingness of employees of the body to assist the consumer in the preparation of the necessary documents; availability of household amenities in the body that provides administrative services.

9. Equality. The criterion of equality presupposes an equal treatment of the subject of public administration to all consumers of administrative services. It also means that the same cases must be decided in the same way, within the same time, with the same requirements, with a strict ban on granting privileges or other benefits, as well as unjustified restrictions.

\section{Problems and prospects of development of the system of administrative services in Ukraine}

The primary problems of development of the system of administrative services in Ukraine are:

1. Deficiencies in legal regulation. The main deficiencies of the current legislation in the field of administrative services in Ukraine are: unregulated criteria for the formation of the lists of services; disorderly legislation on the payment for the services; inconsistency of the bylaws with each other, which leads to different interpretations of the rules by the relevant executive authorities and local governments; lack of monitoring and analysis of legislation on the whole set of administrative services.

2. The complexity and over-regulation of the procedure for providing administrative services. One of the priorities for the development of administrative services is the introduction of effective mechanisms that will reduce the duration of the procedure of providing administrative services, the number of stages within such a procedure, to minimize corruption risks. The adoption of the Law «On Administrative Procedure» is also important in the context of this issue. Establishing at the legislative level the basic principles and rules of the administrative procedure will contribute to the legal certainty and guarantee the observance of the rights of citizens and legal entities.

3. Improper material and organizational conditions to ensure the exercise by the relevant subjects of public administration of the authority to provide administrative services. In particular: inconvenient and limited mode of operation of administrative bodies, which often coincides with the general work schedule of the majority of the population; the presence of large queues in administrative bodies; lack of proper conditions for waiting; lack of proper information on the procedure for providing the service; lack of blanks and 
other forms to be filled out by the consumers of administrative services; lack of alternative ways to apply to administrative bodies for services.

4. Lack of standards for the provision of administrative services, which should contain a set of characteristics of the administrative service that determine its ability to meet the needs of the consumer.

5. Lack of unified criteria for assessing the quality of administrative services. There are still no systematic mechanisms for assessing the quality and effectiveness of public administration entities in providing administrative services. There is no experience in evaluating the activities of public authorities at each stage of the management decision-making process, which is a significant impediment to improving the quality of administrative services and the activities of public authorities in general.

One of the most important areas of public administration development in Ukraine today is the introduction of e-government, in particular the formation of an effective system of accessible and transparent, secure and non-corrupt, least expensive, fast and convenient e-services. To this end, the Order of the Cabinet of Ministers of Ukraine of November 16, 2016 approved the Concept of development of the electronic services system in Ukraine. The next step in achieving this goal was the adoption on July 29, 2019 by the President of Ukraine of the Decree «On some measures to improve access of individuals and legal entities to electronic services». The purpose of this act is to ensure the proper functioning and protection of data in national electronic information resources, the availability and convenience of electronic services for individuals and legal entities, as well as to prevent corruption in the provision of such services. In pursuance of this Decree, on December 4, 2019, the Cabinet of Ministers of Ukraine approved the «Regulations on the Unified State Web Portal of Electronic Services», which defines the purpose, main tasks, functionalities and subjects of the Unified State Web Portal of Electronic Services «Portal Action», the content of the information on it and the order of its input, as well as other issues of functioning of the specified web portal.

The introduction of information and telecommunication technologies in the provision of administrative services will meet the needs of consumers in administrative services through specially designed electronic technologies, as the provision of electronic services is based on the principle of universal access and provides real-time services for the subjects of the application ${ }^{6}$. When implementing electronic administrative services, the following

\footnotetext{
${ }_{6}^{6}$ Бесчастний В.М., Мердова О.М. Адміністративні послуги у системі публічного управління. Менеджер. 2015. № 1 (69).С. 62
} 
services should be available to their users: convenient access to up-todate information about the service through the relevant portal or website; downloading the forms of documents, the submission of which is necessary to obtain an administrative service, or filling out these forms online; online informing the subject of the request about the status of the administrative service (sms-informing is also widely practiced); online payment for the provision of administrative services, if such a fee is set.

The provision of electronic administrative services should be based on the following principles: consumer orientation; accessibility; security and protection of personal data; debureaucratization and administrative simplification; transparency; storage of electronic information (the subjects of the request should be able to receive information about the actions of the subjects of administrative services related to the receipt of their personal data); openness and reuse (the ability of the subjects of administrative services to interact to provide quality and efficient electronic services, using each other's data and technical solutions); technological neutrality; efficiency and effectiveness.

The Law of Ukraine «On Administrative Services» stipulates that administrative services in electronic form are provided through the Unified State Portal of Administrative Services, including through the information systems of state bodies and local self-government bodies integrated with it. The portal is maintained in order to provide access to information on administrative services using the Internet and is an official source of information on the provision of administrative services. From January 1, 2020, the functions of the Unified State Portal of Administrative Services will be performed by the Unified State Web Portal of Electronic Services (Portal). Portal Action is an information and telecommunication system, which organizationally and functionally consists of a register of administrative services, an electronic cabinet, a mobile application of Portal Action (Action), other subsystems and software modules. The Unified state web portal of electronic services has an official address on the Internet diia.gov.ua. The Action Portal is used free of charge 24 hours a day, seven days a week. The Action portal performs the following main tasks:

- provision of electronic services (including administrative and other public services) with the receipt and use, if necessary, of information from national electronic information resources, which is necessary for the provision of such services;

- creation and functioning of the user's electronic cabinet on the web portal, as well as providing users with access to information from national 
electronic information resources, in particular about the person, through the specified cabinet;

- providing users with information about electronic and administrative services, as well as other public services, which are provided using a web portal;

- providing official e-mail during the provision of services, consideration of appeals and administrative cases, as well as during the consideration using the web portal of other issues;

- payment of administrative fees for the provision of administrative services, fines for administrative offenses, state duties, other payments; settlements for other public, in particular housing and communal, services;

- providing the subjects of the application with information on the course and results of the provision of services, consideration of appeals and administrative cases in real time;

- receipt by the subjects of the application of the results of the provision of electronic services, consideration of appeals and administrative cases;

- filing complaints based on the results of providing services, consideration of appeals and administrative cases, providing official e-mail during the appeal procedures, providing the complainant with information on the course and results of the complaint in real time, as well as receiving these results;

- formation by means of a web portal, including with the use of the mobile application of the Action Portal, digital images of documents that can be presented (provided) by a person on a smartphone through the specified mobile application;

- conducting a survey on initiatives, projects in various spheres of public life;

- monitoring and evaluating the quality of services provided using the web portal, in the centres of administrative services or by the subjects of consideration of appeals directly;

- protection of data (including personal) of the specified web portal from unauthorized access, destruction, modification;

- submission of electronic applications through the web portal and others ${ }^{7}$.

Today in Ukraine there are also the following state registers and portals for the provision of administrative and other public services, including in electronic form: Unified state portal for administrative services; section «Electronic services» on the Government portal; Register of administrative

7 Питання Єдиного державного веб-порталу електронних послуг та Єдиного державного порталу адміністративних послуг: Постанова Кабінету Міністрів України від 04.12.2019 р. Дата оновлення: 25.02.2020 p. URL: https://zakon.rada.gov.ua/laws/show/1137-2019-\%D0\%BF. 
services on the website of the Ministry of Economic Development and Trade of Ukraine; electronic administrative services of the State Service for Geodesy, Cartography and Cadastre of Ukraine; electronic administrative services of the State Architectural and Construction Inspectorate of Ukraine; office of electronic services of the Ministry of Justice of Ukraine; electronic services of the State Fiscal Service of Ukraine; Portal of electronic services of the Pension Fund of Ukraine.

At the regional level, local governments and local executive bodies create separate electronic portals (services) for the provision of administrative services. For example, today there is a Regional Virtual Office of Electronic Administrative Services of Dnipropetrovsk region, some administrative services are provided in electronic form through the website of the Center for Administrative Services in Ivano-Frankivsk, the Portal of Electronic Services in Volyn and more. That is, at the local level, local governments create opportunities for the provision of additional administrative services that fall within their competence and are carried out taking into account local characteristics and needs. The iGov.org.ua Public Services Portal operates as a non-governmental project. It is gradually expanding the geography and list of public services that can be obtained electronically ${ }^{8}$.

The introduction of electronic services requires optimization of existing procedures for providing administrative services in order to:

- reduction of the number of documents required from the subject of the application, due to the introduction of interdepartmental electronic interaction, opening of access to state information resources;

- reduction of the number and simplification of the stages provided for in the procedure for providing administrative services;

- introduction of electronic forms of interaction between the subjects of application and the subjects of providing administrative services;

- definition of separate stages (procedures) provided by the order of rendering of administrative service which can be automated;

- reduction of terms of performance of separate stages which are provided by the order of the provision of administrative service, and the general term of the provision of administrative service ${ }^{9}$.

To ensure the development of the system of electronic administrative services, it is necessary to define and plan the stages of development of the

\footnotetext{
${ }^{8}$ Соломко Ю. Надання адміністративних послуг в електронній формі на державному рівні. Ефективність державного управління. 2018. Вип. 1(54). Ч. 1. С. 155.

9 Про схвалення Концепції розвитку системи електронних послуг в Україні: Розпорядження Кабінету Міністрів України від 16.11.2016 р. Дата оновлення: 16.11.2016 p. URL: https://zakon.rada.gov.ua/laws/show/918-2016-\%D1\%80.
} 
system of electronic services. Thus, at the first stage it is envisaged to provide the possibility of remote access of the subject of the appeal to complete, up-to-date and reliable information about the administrative service by means of information, telecommunication, information-telecommunication systems. At the second stage it is provided for the possibility of remote access of the subject to download, fill out and print electronic applications and other documents required to obtain administrative services, using information, telecommunications, information and telecommunications systems. At the third stage, it is envisaged to provide the possibility for the subject of appeal to submit an application and other documents necessary to receive administrative services in electronic form, as well as to pay for the provision of administrative services in electronic form (in the case of paid administrative services). At the fourth stage it is expected to ensure the implementation of all stages (procedures) provided for in the procedure for providing administrative services in electronic form, as well as personalized planning of the need to receive administrative services on the basis of data known about the individuals or legal entities. The fourth stage does not exclude physical contact between the subject of the application and the subject of administrative service, if it is provided by law. The implementation of the third and fourth stages of development of electronic services should provide for the possibility of access of administrative service centres to information on the provision of electronic services in the relevant territory.

The formation of a single information and telecommunication infrastructure that provides electronic services should be carried out according to the conceptual model of the electronic services system. The conceptual model uses a service-oriented approach, a modular principle in order to combine and reuse its components during the introduction of new electronic services and is sufficiently universal for use at both local and national levels. The conceptual model is conventionally divided into three levels: data level, interaction level and presentation level.

To ensure the development of the system of electronic administrative services, it is also necessary to increase the readiness of individuals and legal entities to use electronic services. The benefits of e-services should be clear and accessible to all subjects of application. The media and public organizations should also be involved in promoting the development of the electronic services system. The efforts to increase the readiness of subjects to apply for the use of electronic services should be expanded and modernized by providing: development of appropriate electronic educational resources and development of individual modular training programs of different levels of complexity; 
creation of special places for training of citizens on the basis of a network of libraries, public organizations and volunteer initiatives; development of the distance learning system, including for people with disabilities.

When creating new and reformatting existing administrative services it is necessary to provide:

- maximum automation of all processes in back-offices (administrative service centres should not waste time, data should be transmitted electronically);

- transformation of the state into a service in the centre of which a person (for the convenience of services should be combined by life or business event);

- inclusiveness and accessibility (citizens should receive services in a way convenient for them, for example, by phone);

- introduction of Smart services - services provided by the state without the involvement of citizens and civil servants in connection with a life event (for example, the birth of a child or retirement - a person does not have to prove a bunch of documents that he is entitled to receive assistance);

- once only (if the state already has information about the person, it is not necessary to submit paper confirmations of this information dozens of times) ${ }^{10}$.

\section{CONCLUSIONS}

In view of all the above, it should be highlighted the main areas of the public administration in the field of administrative services that need improvement:

1. Introduction of information and telecommunication technologies in the field of administrative services: improvement and development of the electronic services system (in particular, development of the Portal Action), as well as introduction of information and telecommunication technologies in the work of administrative service centres.

2. Establishment of normatively defined standards for the provision of administrative services and clear criteria by which their quality can be assessed, as well as the introduction of a system for assessing the quality of administrative services in the activities of public administration entities.

3. Simplification and unification of the procedure for providing administrative services, in particular, through the adoption of the Law «On Administrative Procedure».

${ }^{10}$ Як відбуватиметься трансформація публічних послуг в Україні. Портал реформи адміністративних послуг. 2019. URL: https://cnap.in.ua/luydmyla_rabchynska_public_services/ 
4. Optimization of the network of administrative service centres and continuation of the process of decentralization of administrative services, which provides that most of these services should be provided at the level of local governments.

5. Development and normative definition of the issue of pricing of administrative services, with obligatory definition of uniform criteria and establishment of commensurability of the price and quality of the corresponding administrative service.

6. Creation of appropriate material, financial and organizational conditions to ensure the activities of public administration entities to provide administrative services.

\section{SUMMARY}

The article is devoted to the study of public administration in the field of administrative services in Ukraine. It is established that improving the provision of administrative services today is one of the key areas of reform processes in Ukraine, and the formation of effective mechanisms for providing quality administrative services is one of the priorities of public administration. The need to improve the current legislation in the field of administrative services, revision of procedural standards for their provision, as well as the introduction of information and telecommunications technologies in the provision of administrative services determines the relevance of the study of this issue. The concepts and features of administrative services are considered. It is determined that a necessary condition for improving the efficiency of public administration in the field of administrative services is to assess the quality of administrative services, which should be based on the following criteria: availability, efficiency, timeliness, convenience, openness, minimum (fair) cost of administrative services and affordability, professionalism, respect for the person and equality. Problems in the provision of administrative services in Ukraine are studied, among which are the following: shortcomings in legal regulation, complexity and irregularity of the procedure for providing administrative services, lack of standards for providing administrative services, lack of uniform criteria for assessing the quality of administrative services. It is determined that the issues of developing a mechanism for introducing information and telecommunication technologies into the provision of administrative services are becoming especially relevant today. The main directions of public administration in the field of administrative services that need improvement are highlighted. 


\section{REFERENCES}

1. Бесчастний В.М., Мердова О.М. Адміністративні послуги у системі публічного управління. Менеджер. 2015. № 1(69). С. 58-64.

2. Лавренова О.І. Оцінювання якості надання адміністративних послуг : навчальний посібник / О.І. Лавренова, Т.І. Білоус-Осінь, С.К. Могил. Одеса, 2019.56 c. URL: https://hdl.handle.net/11300/12475. DOI 10.32837/11300.12475.

3. Легеза Є.О. Щодо визначення публічних послуг в Україні. Юридичний науковий електронний журнал. 2015. № 6. С. 129-131.

4. Питання Єдиного державного веб-порталу електронних послуг та Єдиного державного порталу адміністративних послуг : Постанова Кабінету Міністрів України від 04.12.2019 р. Дата оновлення: 25.02.2020 р. URL: https://zakon.rada.gov.ua/laws/show/1137-2019-\%D0\%BF.

5. Про адміністративні послуги : Закон України від 06.09.2012 р. Дата оновлення: 19.04.2020 p. URL: https://zakon.rada.gov.ua/laws/show/5203-17.

6. Про схвалення Концепції реформування місцевого самоврядування та територіальної організації влади в Україні : Розпорядження Кабінету Міністрів України від 01.04.2014 р. Дата оновлення: 01.04.2014 p. URL: https://zakon.rada.gov.ua/laws/show/333-2014-\%D1\%80.

7. Про схвалення Концепції розвитку системи надання адміністративних послуг органами виконавчої влади : Розпорядження Кабінету Міністрів України від 15.02.2006 р. Дата оновлення: 15.02.2006 р. URL: https://zakon.rada.gov.ua/laws/show/90-2006-\%D1\%80.

8. Про схвалення Концепції розвитку системи електронних послуг в Україні : Розпорядження Кабінету Міністрів України від 16.11.2016 p. Дата оновлення: 16.11.2016 p. URL: https://zakon.rada.gov.ua/ laws/show/918-2016-\%D1\%80.

9. Соломко Ю. Надання адміністративних послуг в електронній формі на державному рівні. Ефективність державного управління. 2018. Вип. 1(54). Ч. 1. С. 151-157.

10. Як відбуватиметься трансформація публічних послуг в Україні. Портал реформи адміністративних послуг. URL: https:/cnap.in.ua/ luydmyla_rabchynska_public_services/.

\section{Information about author:}

Lavrenova O. I., $\mathrm{PhD}$ in Law, Associate Professor at the Department of Administrative and Financial Law National University "Odesa Law Academy" 23, Fontanska doroha str., Odesa, 65009, Ukraine 